\title{
Neuronal hyperplasia in clinically diagnosed acute appendicitis: A histopathological study in a tertiary care centre
}

\author{
Riddhi A Parmar ${ }^{1}$, Riti Piyush Dixit ${ }^{2}$, Keval A Patel ${ }^{1}$, Bhawana S Sharma ${ }^{1}$, \\ Jigna Dave ${ }^{1}$
}

${ }^{I}$ Department of Pathology, Gujarat Adani Institute of Medical Sciences, Gujarat, India

2Department of Pathology, GMERS Medical College, Gujarat, India

\author{
Keywords: \\ Appendicitis; \\ Appendectomy; \\ Neuronal hyperplasia;
}

\begin{abstract}
Background: Acute appendicitis is one of the most common general surgical emergencies. Around $20-25 \%$ of patients who have an appendectomy done are found not to have acute appendicitis on histopathological examination. There is increasing evidence of the involvement of the enteric nervous system, in the immune regulation and monitoring the inflammatory responses. The present study was done to elucidate if neuronal changes in the appendix could be the cause of clinical acute.
\end{abstract}

Materials and methods: Hospital records of 60 cases who were diagnosed as acute appendicitis clinically and who underwent appendectomy either laparoscopic or open, were reviewed. Histopathological records of these resected appendices submitted to the department of histopathology, GAIMS, G.K. General Hospital Bhuj were reviewed for one year for the presence or absence of acute appendicitis or neuronal hyperplasia. Routine Haematoxylin and Eosin stain and S-100 protein staining was done on all these 60 cases.

Results: Out of these 60 specimens of appendices received, histopathological examination revealed neuronal hyperplasia in the submucosa and muscularis layer on all the 60 cases. Grading of neuronal hyperplasia was done in all the cases. Out of these 60 specimens of appendices, histopathological examination revealed 48 cases of histopathologically positive acute appendicitis and 12 cases of histopathologically negative acute appendicitis.

Conclusions: Neuronal hyperplasia has an important role in the pathogenesis of appendiceal colic in patients with both histopathologically positive acute appendicitis and histopathologically negative acute appendicitis.

\section{Correspondence:}

Dr. Riti Piyush Dixit, MD

Associate Professor, Department of Pathology, GMERS Medical College, Vadnagar,

Gujarat, India-384265

ORCID ID: 0000-0002-2377-6675

Email: rsinha75@gmail.com

Received : September $22^{\text {nd }} 2020 ;$ Accepted : February $14^{\text {th }} 2021$

Citation: Parmar RA, Dixit RP, Patel KA, Sharma BS. Neuronal hyperplasia in clinically diagnosed acute appendicitis: A histopathological study in tertiary care centre J Pathol Nep. 2021;11:1864-7. DOI: $10.3126 /$ jpn.v11i1.31402

Copyright: This is an open-access article distributed under the terms of the Creative Commons Attribution 4.0 International License, which permits unrestricted use, distribution, and reproduction in any medium, provided the original author and source are credited.

\section{INTRODUCTION}

The appendix is an intriguing organ, keeps challenging the clinicians and pathologists. Acute appendicitis is the most common surgical emergency. ${ }^{1}$

Appendectomy is the most frequently performed operation worldwide. Nearly $20 \%$ of patients who undergo appendix resection are found not to have features of acute appendicitis on histopathological examination. ${ }^{2}$ Obstruction of the lumen, leading to distension and disordered accumulation, lymphoid hyperplasia, and fibrosis are causative factors for the pathogenesis of acute appendicitis. However, microorganism infestation of the appendix is the last event in 
the pathogenesis of acute appendicitis. ${ }^{3}$ Even in the absence of acute appendicitis, removal of the appendix relieves pain, suggesting the interaction between local endocrine cells and neural hyperplasia of the enteric nervous system. ${ }^{4}$

Immunocompetent cells like the mast cells, with their important role in hypersensitivity reactions, are closely opposed to the nerves in the gastrointestinal tract. By releasing neurotrophic factors, they might be involved in neuronal hypertrophy of the appendix. In acute appendicitis, the relationship between the enteric nervous system and inflammatory cells has been described. ${ }^{5-7}$

\section{MATERIALS AND METHODS}

Appendectomy specimens were received from the department of surgery and fixed in buffered formalin, and sections were taken at three levels, tip, middle, and base. After being embedded in paraffin sections were taken at five micrometers and stained with routine hematoxylin and eosin stain (H\&E) and by immunohistochemistry (IHC) S100 protein. The 60 surgically resected appendices with the clinical diagnosis of acute appendicitis were divided into two categories: 1) Histopathologically positive acute appendicitis and 2) Histopathologically negative acute appendicitis

Criteria for diagnosis of histopathologically positive acute appendicitis (at least three out of six) are as follows:

1. Neutrophils infiltrating throughout the muscle layer.

2. Neutrophils present in the submucosa.

3. Epithelial erosion (denudation of the columnar lining epithelium)

4. Suppurative Inflammation (Abscess)
5. Vasodilation and edema.

6. Fibrinous exudate along with acute inflammatory cells over the serosa.

Exclusion Criteria included occasional scattered inflammatory cells within the lumen or serosa, perivascular neutrophils infiltrate, perforated appendix, and Gangrenous Appendix (due to major structural damage to the lamina propria, submucosa, and muscle layer will obscure the neural tissue) and or appendiceal fibrosis

Criteria for diagnosis of histopathologically negative acute appendicitis (at least two out of three shall be present) are as follows:

1. Absence of neutrophils in the muscularis propria

2. Intact lining epithelium.

3. Presence or absence of lymphoid hyperplasia.

The ganglion plexus present in the submucosa and muscularis propria was identified. 10 non-overlapping contiguous fields were examined under high power and an average per HPF was calculated and graded:8

Grade 1+ (Mild Hyperplasia) : $<1 / \mathrm{HPF}$

Grade 2+ (Moderate hyperplasia): 1/ HPF

Grade 3+ (Marked hyperplasia) : >1/ HPF

\section{RESULTS}

A total of 60 cases were studied during the study period. Out of the total 60 cases, there were 48 cases $(80 \%)$ of histologically positive acute appendicitis (HPAAand 12

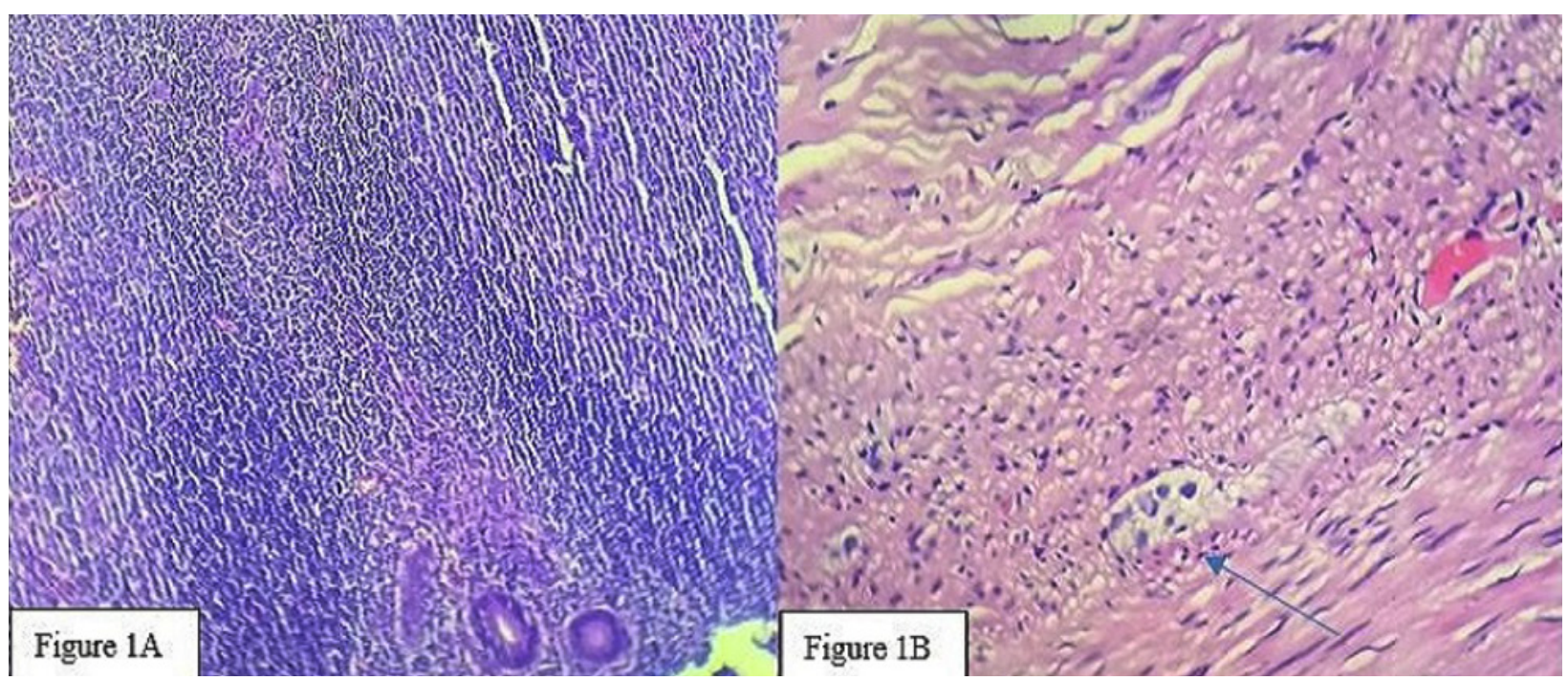

Figure 1: Photomicrograph showing neural hyperplasia i, a) submucosa and b) muscularis propria (HE stain; a) X100, b) X400). 


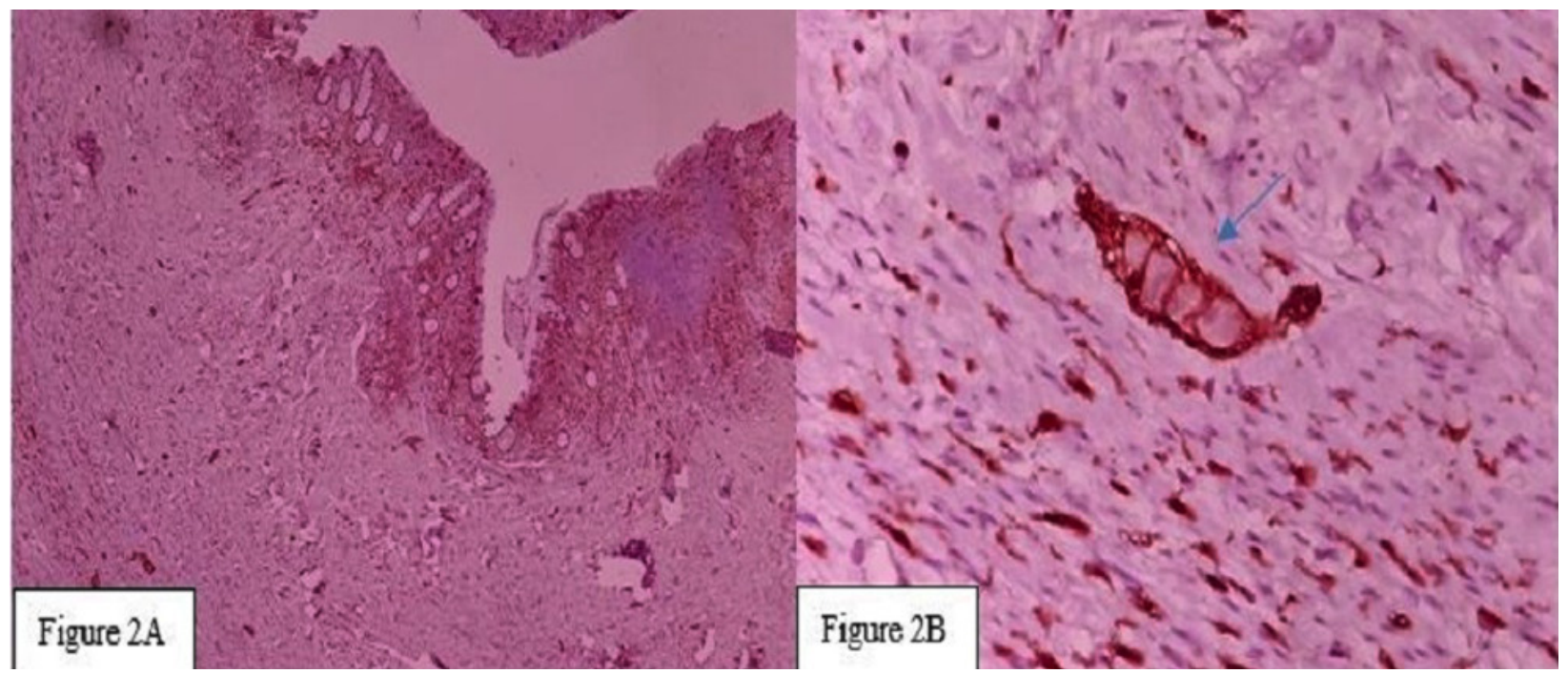

Figure 2: S100 immunostain showing submucosal neural hyperplasia (X50) and in between the muscularis propria (X100).

cases $(20 \%)$ of histologically negative acute appendicitis (HPNA). Among the total HPAA patients, grade 1 neuronal hyperplasia was observed in $18 / 48(37.5 \%)$ cases. Grade 2 neuronal hyperplasia was encountered in $22 / 48(45.8 \%)$ and grade 3 was n 8/48 (16.67\%) patients with acute appendicitis. Out of the 12 cases of HPNA, grade 1 neural hyperplasia was seen in 9/12 (75\%) cases and grade 2 was seen in 3/12 (25\%). Neuronal hyperplasia was observed in both submucosa and muscularis propria (fig. 1 and 2)

\section{DISCUSSION}

Appendiceal neuroma or neurogenic hyperplasia of the appendix was first described by Pierre Masson in $1928 .{ }^{9}$ It is a relatively common entity characterized by the obliteration of the lumen of the appendix by a proliferation of neural tissue.

Possibly, there is an increase in the number of enteroendocrine cells leading to the hyperplastic proliferation of unmyelinated neurons and Schwann cells.10 There is increasing evidence supporting the involvement of the enteric nervous system in immune regulation of the body. Lymphocytes and mast cells are in a close functional relationship with the enteric nervous system. Studies have also suggested the presence of receptors for neuropeptides on the immunocompetent cells throughout the gastrointestinal tract (GIT). ${ }^{11-14}$

Increased nerve proliferation and increased levels of a neurotransmitter (substance P)4 and vasoactive intestinal peptide $^{15}$ has been reported in associated with chronic inflammatory bowel disease $e^{5,7}$ and appendiceal fibrosis. Appendiceal fibrosis is a fibrotic lesion in which there are more Schwann cells and mast cells as compared to fibroblasts. ${ }^{15}$

In the present study, the neural tissue was highlighted by
S100 stain but was equally identifiable in routine HE stains. Inflammatory reactions involving the local endocrine cells and neuro-proliferation may cause repeated and chronic attacks of appendiceal colic. ${ }^{16}$

Grade 1neural hyperplasia was seen in $37.5 \%$ cases of histopathologically positive acute appendicitis and $75 \%$ cases of histopathologically negative acute appendicitis. Grade 2 neural hyperplasia was highest and seen in $45.8 \%$ of cases of histopathologically positive acute appendicitis. This finding of neural hyperplasia being more common in HPAA was similar to other studies but differed from two other studies. $^{8,17}$

The pathogenesis of neural hypertrophy in acute appendicitis is still not known. It may represent a form of inflammatory response. The extent of neuronal proliferation seen in the present study is unlikely to develop due to a single attack of acute inflammation. These suggest either repeated bouts and subclinical inflammation or obstruction in the lumen of the appendix. Xiong et $\mathrm{al}^{18}$ also supported the above concept of neuronal proliferation.

\section{CONCLUSIONS}

Neural hyperplasia may represent an early identifiable morphological feature of inflammation. Hence the present study was conducted and the finding of an increase in neural components in histopathologically positive acute appendicitis suspected a functional link between the enteric nervous system, mast cells, and pathogenesis of the colic in acute appendicitis.

\section{Acknowledgement}

I would like to express my sincere gratitude to our head of the department, my colleagues and all the technicians 
(Histopathology section) for helping me out during the study period. I also thank the interns and residents of the Department of Surgery.

Conflict of interest: None

\section{REFERENCES}

1. Marudanayagam R, Williams GT, Rees BI. Review of the pathological results of 2660 appendicectomy specimens. J Gastroenterol. 2006; 41(8):745-9. Crossref

2. Khan GM, Grillo IA, Abu-Eshy SA, Khan AR, Mubarak J, Jastaniah S. Pathology of the appendix. J Natl Med Assoc. 2000; 92(11):533-5.

3. Bharathi RS, Sharma V, Chakladar A, Kumari P. Port extériorisation appendectomy-our experience. Med J Armed Forces India. 2011; 67(2):147-151.

4. Jovanovic K, Siebeck M, Gropp R. The route to pathologies in chronic inflammatory diseases characterized by $\mathrm{T}$ helper type 2 immune cells. Clin Exp Immunol. 2014; 178(2):201-11. $\underline{\text { Crossref }}$

5. Castro GA, Harari Y, Russell D. Mediators of anaphylaxis-induced ion transport changes in small intestine. Am J Physiol. 1987; 253: G540-8. $\underline{\text { Crossref }}$

6. Stead RH, Tomioka M, Quinonez G, et al. Intestinal mucosal mast cells in normal and nematode-infected rat intestines are in intimate contact with peptidergic nerves. Proc, Natl, Acad, Sci, USA 1987; 84:2975-9. $\underline{\text { Crossref }}$

7. Stead RH, Dixon MF, Bramwell NH, Riddell RH, Bienenstock J. Mast cells are closely apposed to nerves in the human gastrointestinal mucosa. Gastroenterology. 1989; 97(3):575-85. Crossref

8. Safeena A, Mathai AM, Naik R, Pai M, Kumar S, Prasad K. Neuronal hypertrophy and mast cells in histologically negative, clinically diagnosed acute appendicitis: a quantitative immunophenotypical analysis. Indian J Gastroenterol, 2010: 29(2): 69-73. $\underline{\text { Crossref }}$
9. Masson P. Carcinoids (Argentaffin-Cell Tumors) and Nerve Hyperplasia of the Appendicular Mucosa. Am J Pathol. 1928; 4(3):181-212.19.

10. Aubock L, Ratzenhofer M. "Extraepithelial enterochrmaffin cell- nerve fibre complexes" in the normal appendix, and in neurogenic appendicopathy. $\mathrm{J}$ Pathol. 1982; 136:217-26. $\underline{\text { Crossref }}$

11. Pascual DW, Beagley KW, Kiyono H, McGhee JR. Substance P promotes Peyer's patch and splenic B-cell differentiation. Adv Exp Med Biol. 1995; 371A: 55-9. Crossref

12. Goettxl EJ, Xia M, Ingram DA, et al. Neuropeptide signalling of lymphocytes in immunological responses. Int Arch Allergy Immunol. 1995; 170:202-4. $\underline{\text { Crossref }}$

13. Mantyh CR, Vigna SR, Bollinger RR, Mantyh PW, Maggio JE, Pappas TN. Differential expression of substance P receptors in patients with Crohn's disease and ulcerative colitis. Gastroenterol. 1995; 109:850-60. $\underline{\text { Crossref }}$

14. Swain MG, Agro A, Blennerhasset P, Stanisz A, Collins SM. Increased levels of substance $P$ in the myeteric plexus of Trichinella-infected rats. Gastroenterol.1992; 102:1913-9. Crossref

15. Stead RH, Franks AJ, Goldsmith $\mathrm{CH}$, Bienenstock J, Dixon MF. Mast cells, nerves and fibrosis in the appendix a morphological assessment. J Pathol. 1990; 161:209-19. Crossref

16. Laszlo Nemeth, Udo Rolle, Denis J. Reen, and Prem PuriArchives of Pathology \& Laboratory Medicine 2003 127:5, 573-8. $\underline{\text { Crossref }}$

17. Franke C, Gerharz CD, Böhner H, et al. Neurogenic appendicopathy: a clinical disease entity? Int J Colorectal Dis. 2002; 17(3):185-91. $\underline{\text { Crossref }}$

18. Xiong S, Puri P, Nemeth L, O'Briain DS, Reen DJ. Neuronal hypertrophy in acute appendicitis. Arch Pathol Lab Med 2000; 124:1429-33. Crossref 